Florida International University FIU Digital Commons

4-18-2012

\title{
Family Form, Desired Parental Involvement and Troubled Ruminations about Fathers and Mothers
}

Alina Nazareth

Florida International University, anaza003@fiu.edu

DOI: $10.25148 /$ etd.FI12071104

Follow this and additional works at: https://digitalcommons.fiu.edu/etd

\section{Recommended Citation}

Nazareth, Alina, "Family Form, Desired Parental Involvement and Troubled Ruminations about Fathers and Mothers" (2012). FIU

Electronic Theses and Dissertations. 650.

https://digitalcommons.fiu.edu/etd/650

This work is brought to you for free and open access by the University Graduate School at FIU Digital Commons. It has been accepted for inclusion in FIU Electronic Theses and Dissertations by an authorized administrator of FIU Digital Commons. For more information, please contact dcc@fiu.edu. 


\title{
FLORIDA INTERNATIONAL UNIVERSITY
}

Miami, Florida

\section{FAMILY FORM, DESIRED PARENTAL INVOLVEMENT AND TROUBLED RUMINATIONS ABOUT FATHERS AND MOTHERS}

\author{
A thesis submitted in partial fulfillment of \\ the requirements for the degree of \\ MASTER OF SCIENCE \\ in \\ PSYCHOLOGY \\ by
}

Alina Nazareth 
To: Dean Kenneth Furton

College of Arts and Sciences

This thesis, written by Alina Nazareth and entitled Family Form, Desired Parental Involvement and Troubled Ruminations about Fathers and Mothers, having been approved in respect to style and intellectual content, is referred to you for judgment.

We have read this thesis and recommend that it be approved.

Mary J. Levitt

Robert Lickliter

Gordon Finley, Major Professor

Date of Defense: April 18, 2012

The thesis of Alina Nazareth is approved.

$\begin{array}{r}\text { Dean Kenneth Furton } \\ \text { College of Arts and Sciences } \\ \hline \begin{array}{r}\text { Dean Lakshmi N. Reddi } \\ \text { University Graduate School }\end{array}\end{array}$

Florida International University, 2012 
(c) Copyright 2012 by Alina Nazareth

All rights reserved. 


\section{DEDICATION}

I dedicate this thesis to my parents. Without you, I would never have had the courage to move to a new country and to dream new dreams 


\section{ACKNOWLEDGMENTS}

I would like to thank my major professor Dr. Gordon Finley, for the time and energy he has invested in this research project. His strong conceptual and theoretical insights pushed me to delve deeper into divorce literature and to develop a keen interest in the subject.

I would also like to thank Dr. Paulette Johnson for her assistance during the data-analysis stage. Her willingness to revisit the statistical analysis countless times helped me in interpreting and presenting the data in the best way possible.

Last, but not the least, I would like to thank my committee members Dr. Mary J. Levitt and Dr. Robert Lickliter for their time and support throughout the process. 


\begin{abstract}
OF THE THESIS
FAMILY FORM, DESIRED PARENTAL INVOLVEMENT AND

TROUBLED RUMINATIONS ABOUT FATHERS AND MOTHERS
\end{abstract}

\author{
by
}

Alina Nazareth

Florida International University, 2012

Miami, Florida

\title{
Professor Gordon Finley, Major Professor
}

This study is an exploration of the relationship between retrospectively perceived desired parental involvement and current troubled ruminations about fathers and mothers by young adults. It investigates the impact of family form on desired parental involvement and troubled ruminations. The data were taken from a larger project (Finley, Mira, \& Schwartz, 2008), consisting of 1,714 ethnically diverse, young adult university students.

The results show a significant correlation between desired paternal involvement and troubled ruminations about fathers $(r=.369, p<.001)$ and $a$ significant correlation between desired maternal involvement and troubled ruminations about mothers $(r=.201, p<.001)$. There was a significantly higher association between desired parental involvement and troubled ruminations for fathers $(r=.411)$ as compared to mothers $(r=.248), p<.001$ in divorced families. Given the current social policies favoring maternal custody following divorce (resulting in lower paternal involvement), a better understanding of the paternal role and its impact may contribute to shaping better family policy. 


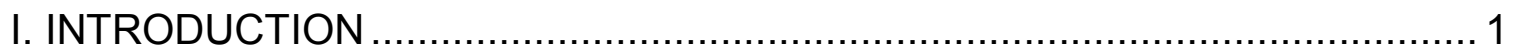

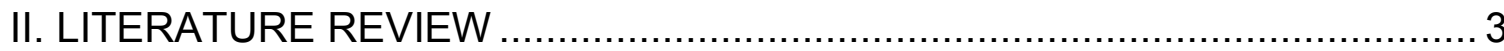

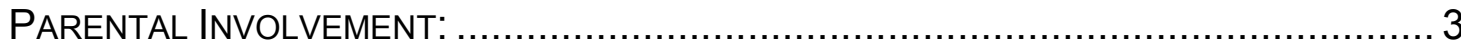

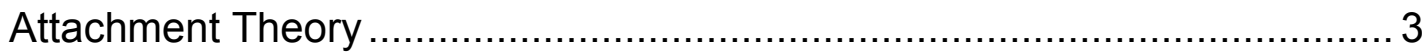

CURRENT TRENDS IN PARENTAL INVOLVEMENT:............................................ 4

Parental Involvement in Intact Families .......................................... 5

Maternal employment ................................................................. 5

Parental Involvement in Divorced/ Separated Families .............................. 6

The non-resident father .................................................................. 7

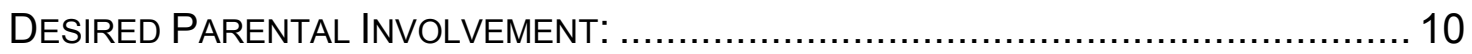

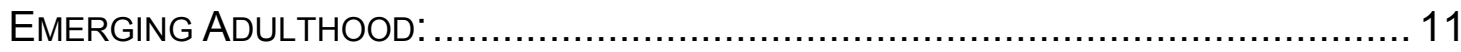

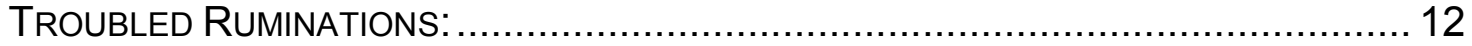

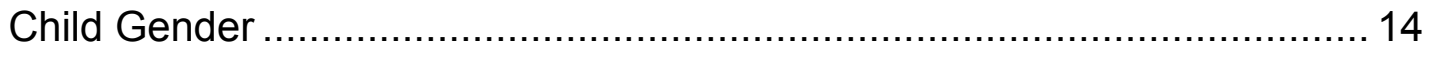

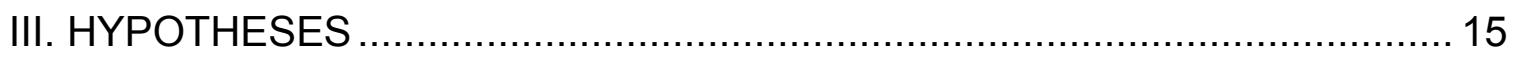

IV. METHOD

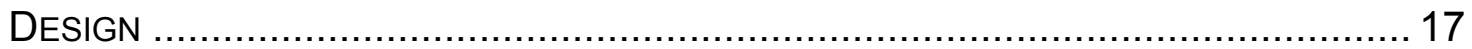

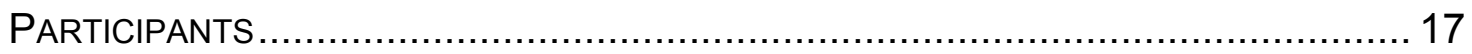

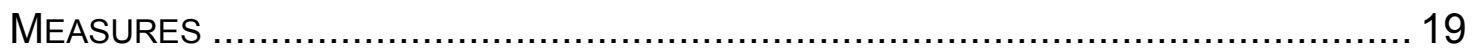

Troubled Ruminations about Parents ............................................... 19

Maternal and Paternal Desired Involvement........................................... 20

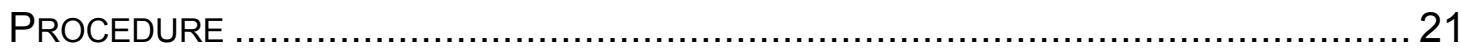

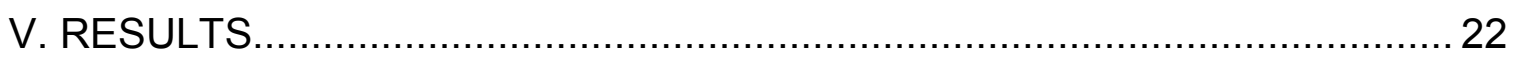

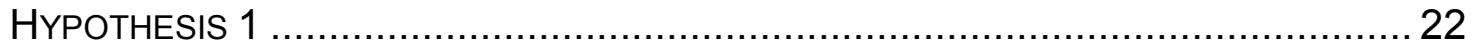

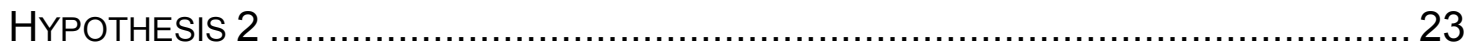

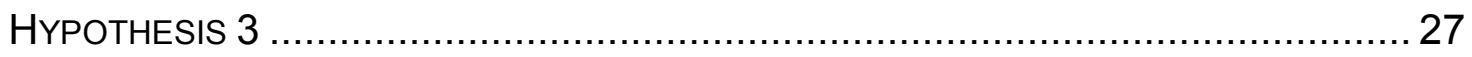

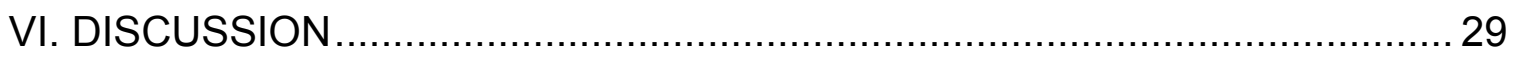

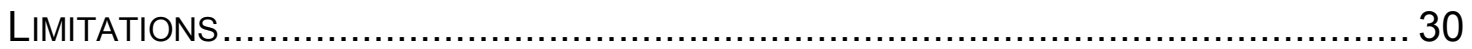

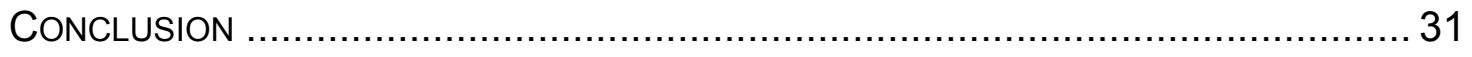

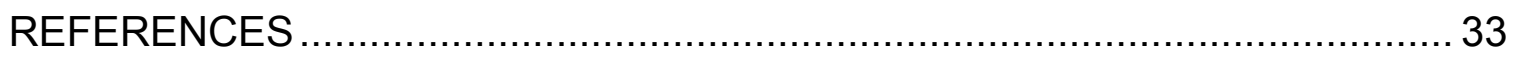




\section{INTRODUCTION}

The 'troubled ruminations' construct was introduced by Schwartz and Finley (Finley \& Schwartz, 2010; Schwartz \& Finley, 2010). Troubled ruminations allude to the feeling among young adults that one or both of their parents caused pain in their families, that the non-resident parent was not interested in spending time with them, that their parents may not have loved them, and that they are dissatisfied with their relationship with one or both parents. However, since troubled ruminations as a construct was introduced only in 2010 , there has been no follow up research done on it.

While there is evidence that desired father involvement is significantly higher in participants from divorced families as compared with participants from intact families (Schwartz \& Finley, 2005), research on the effect of family form on troubled ruminations about fathers and mothers as well as the relationship between troubled ruminations and desired parental involvement would be an important contribution to research guiding family law and social policy.

As a subset of the family form research, the role of the non-resident father as an attachment figure is often times limited to financial support. As it is, the traditional instrumental role played by the father may no longer meet a child's expectations (Finley \& Schwartz, 2006). Research on the nature of desired paternal involvement, i.e., expressive and instrumental would help broaden the current limited definition of father involvement.

From a developmental-lifespan perspective, there is a growing body of research on emerging adulthood, as a new theoretically and empirically distinct 
developmental period of the human lifespan. As a newly identified (and contested) developmental stage, there is a need to plug the gaps in research in order to enhance our understanding of this period of life. An unexplored area of research is the impact that experiences during childhood have on the psychosocial development of the emerging adult (or young adult as an alternative term used in some literature).

The current study aims at furthering research in all these areas. What we do know at this point is that troubled ruminations during emerging adulthood have been shown to be significantly related to low self-esteem, lack of purpose in life, poor life satisfaction, romantic relationship problems and psychological stress (Schwartz \& Finley, 2010). If a correlation can be established between a desire for increased parental involvement and troubled ruminations during emerging adulthood, it would provide evidence in support of the lasting impact of parent-child experiences, stretching well into emerging adulthood. Thus it could act as a guideline to parents about the parenting strategies adopted while raising a child and their long-term impact.

The current study addresses gaps in the existing body of research in three distinct ways. First, it enhances our understanding of troubled ruminations which is a recently introduced construct based on a negative internal working model. Second, it increases our understanding of emerging adulthood as a new developmental phase and the extent to which childhood attachment figures impact it. Third, it expands on the much-needed research on the importance 
and role of the non-resident father in the developmental and psychosocial wellbeing of his child.

\section{LITERATURE REVIEW}

Parental Involvement:

There is a large body of research confirming the importance of parental involvement in the developmental and psychosocial wellbeing of children. Children's sense of emotional security, comfort and wellbeing is usually dependent on the quality of the relationship with their parents. Thus, parents subscribe to the definition of an attachment figure in both PARTheory and attachment theory (Ainsworth, 1989; Rohner, 2004). However, the role of an attachment figure is not restricted to infancy alone. There is substantial evidence that high levels of parental involvement significantly affect adolescent wellbeing (Wenk, Hardesty, Morgan, \& Blair, 1994).

\section{Attachment Theory}

The theory states that within the first 7 months, the first attachments are generally formed to a few persons and virtually all infants become attached (Main, 1996; Watson, 1972). Infants may even be attached to insensitive and maltreating parents (Ainsworth, Blehar, Waters, \& Wall, 1978). This attachment, even to insensitive parents, needs to be taken into account by researchers who advocate that children of high-conflict homes are worse off than children of

divorce. While on the one hand a divorce may save the child from a high-conflict environment, the estrangement from one parent because of custody and 
visitation limitations may increase stress. While older individuals may be less governed by attachment behavior, there exists a propensity to monitor the accessibility of attachment figures and to seek them as "stronger and wiser" in times of stress throughout the lifespan (Bowlby, 1980). Divorce and sole-mother or sole-father custody, deprives the child of one of the attachment figures, which in turn, could have negative results on the child. The extent of this negative impact cannot fully be assessed, as we do not yet understand the processes permitting individuals to change attachment figures (Main, 1996). In addition, most attachment research, unfortunately, is limited in that it tends to be very focused on mother-child bond formation and maternal deprivation effects. This bias in the literature has restricted our understanding of the father-child bond formation and the effects of paternal deprivation.

\section{Current Trends in Parental Involvement:}

The family as a fundamental unit of society has been undergoing major structural changes. These include the proportion of births occurring out of wedlock, the proportion of marriages ending in divorce, postponed marriage and child bearing, smaller family size, single parent families, step families and dual earner families (Demo, 1992). According to Demo (1992) some modest changes occurred during the 1970s with regard to parental involvement in childcare. As opposed to the 60s, when men spent an average of 11 hours and women an average of 35-45 hours per week on childcare, the 70's saw no changes in men's involvement but a definite decrease in the amount of time women spent in child care, thus reducing the overall amount of parental involvement children received 
per week (Coverman \& Sheley, 1986). Pleck (1979) reported that by 1977 men with employed wives spent more hours per week on domestic work and childcare than those with non-employed wives. Although the proportion of men's housework has increased married women continue to spend twice as much time as their husbands on housework and $50 \%$ more time in child care (Barnett \& Baruch, 1987; Robinson \& Milkie, 1998).

\section{Parental Involvement in Intact Families}

In intact families, parental involvement may have decreased over the years due to a significant change in lifestyle across cultures. Dual- income families today are less the exception and more the norm. The added pressure of balancing a career and a family may have resulted in less time being available for childcare. The rise in other stress related factors like traffic and commute time may also result in a lower parental involvement. Children may also perceive parental involvement to be low when in comparison to that received by siblings or other children in school. As a result of the increased external stressors, parents and adolescents spend very little time together, often no more than one hour per day of direct interaction (Demo, 1992).

\section{Maternal employment}

Sixty percent of married mothers with school age children were in the labor force in March 1984, compared with $40 \%$ in 1970 . It is also no longer the case that mothers with very young children stay out of the workforce (Greenberger, Goldberg, Crawford, \& Granger, 1988). While research on the 
effects of working mothers on a child's development has been split, documenting both adverse effects (Greenberger et al., 1988) as well as positive effects (Parcel \& Menaghan, 1990), the rising cost of living and single /unwed motherhood has ensured that more and more women enter the workforce. As a result of women entering the workforce, the percentage of time mothers devoted to the home and children in earlier times has been considerably reduced (Demo, 1992). While part-time employment did have positive effects on adolescent children, this did not hold true for full-time employment (Hoffman, 1974). On the other hand, maternal employment has significantly affected the division of labor between husband and wife, with husbands of employed women helping more in household chores including childcare. The fact that this would lead to a more balanced relationship with both parents has been viewed in a favorable light (Hoffman, 1974).

\section{Parental Involvement in Divorced/ Separated Families}

Divorce tends to give rise to a host of adverse effects including decrease in the quality of family functioning and an increased feeling of being caught between parents (Hartman, Magalhães, \& Mandich, 2011). The increasing number of marriages that are ending in divorce has increased the number of children growing up with little or no contact with one or both parents. In fact, fifty percent of first marriages that occurred in the 80 s are expected to end in divorce even as the rate of cohabitation increases (Miller, Sassler, \& Kusi-Appouh, 2011). In divorced/separated families, in addition to the problems experienced in intact 
homes, there are several more obstacles faced by both sets of parents. Family systems theory posits that spouses exert an influence on each other, which continues, even after-divorce (Ahrons, 1981). In divorced families, parental involvement may be further constrained as a result of the lack of a support system to the custodial parent as well as the legal/ social restrictions on the noncustodial parent. Children's perception of their relationships with a mother and a father were found to be more important in determining children's wellbeing than the physical presence of the father (Wenk et al., 1994). Society tends to use an individual's failure in a marital relationship as an indication of potential failure as a parent. This failure to differentiate between the spouse-role and the parent-role could exacerbate the decline in parental involvement due to the resulting doubts and guilt generated in parents (Spillman, Deschamps, \& Crews, 2004). The continuing relationship between divorced parents is an important factor contributing to the child's post-divorce adjustment (Ahrons, 1981). Co-parenting post-divorce requires that the divorced spouses separate their spousal and parental roles, terminating the former while somehow managing to not only hold on to the latter but also redefining it (Ahrons, 1981).

\section{The non-resident father}

In the case of a divorce, very often, the role of the father is reduced to child support and the complexities associated with the changed relationship tend to get ignored. Fortunately, there is a recent trend towards recognizing paternal importance and fatherhood post-divorce (Booth, 1998). Fatherhood has been 
undergoing a significant transformation, both in definition and in social expectations over the last three to four decades. Many researchers today strongly assert that father presence has a large impact on the wellbeing of children and adolescents (Almeida \& Galambos, 1991; Lamb, Pleck, Charnov, \& Levine, 1987). Unfortunately, societal beliefs continue to treat mothers as the "naturally" better parent. In addition, the legal system continues to define paternal involvement in terms of financial support (Spillman et al., 2004). Given this primitive standpoint, it is no wonder then that almost $90 \%$ of the time, the mother receives full custody, restricting the father to a few weekends and occasional vacations (Stephens, 1996). The vast majority of divorced fathers are noncustodial parents and a large portion of these non-custodial fathers have infrequent or no contact with their children (Dudley, 1991). It has been seen that paternal involvement after divorce decreases and continues to decline in the intervening years (Spillman et al., 2004). According to Stephens (1996), approximately $50 \%$ of children in single-parent households have little or no contact with their fathers and only $25 \%$ of children see their fathers once per week. There are many speculations regarding the reasons for the decline in paternal visitation post-divorce. These include: attempts to avoid 're-experiencing the loss' associated with the end of each visitation (Dudley, 1991), high-conflict with the mother who is the resident parent and who controls the child's activities (Dudley, 1991), inability to pay child support resulting in the legal termination of visitation rights, relocation of one of the parents to a different city (Furstenberg, Nord, Peterson, \& Zill, 1983; Koch \& Lowery, 1984), remarriage (Dudley, 1991; 
Furstenberg et al., 1983; Tepp, 1983), low pre-divorce level of involvement, doubts about true-paternity, fathers own perception of fatherhood, substance abuse problems (Dudley, 1991), fear of making mistakes, demands of their jobs (Dudley, 1991), fear of rejection, physical health problems (Dudley, 1991) and a desire not to confuse children (Dudley, 1991). Until recently, the reasons for infrequent visitations were gathered from the mother's perspective. However, when data were gathered from the fathers directly, it was found that their former spouses were the primary hurdle to increased involvement with children postdivorce (Dudley, 1991; King, 1994). Fabricius \& Hall (2000) found in their study of 800 young adults that forty percent of their respondents reported that their mothers had wanted them to see their fathers either minimally or not at all, or only some of the time and only $7 \%$ felt their mothers had wanted them to spend equal amounts of time with each parent. In addition, it was found that of the total participants, $60 \%$ wanted unrestricted contact with the non-custodial parent. Hence, even though there may be a lack of contact between the spouses postdivorce or between the non-custodial parent and the child, a strong degree of paternal emotional attachment continues to be desired (Fabricius, 2003). In their study of college student's perspectives on living arrangements post-divorce, Fabricius (2003) found that $70 \%$ of both men and women wanted equal amounts of time with both parents. Most of the remaining $30 \%$ chose substantial number of overnights with their father. The living arrangements, post-divorce are generally not flexible even as children grow older and their needs vary (Wallerstein \& Lewis, 1998). In an earlier study, Schwartz \& Finley (2005) 
reported that participants from divorced families reported greater levels of desired father involvement than did participants from intact families.

Desired Parental Involvement:

Children's perceptions of parental involvement have a significant impact on their wellbeing (Wenk, Hardesty, Morgan, \& Blair, 1994). Troubled ruminations provide insight to the degree to which young adults are influenced by thoughts and perceptions of their childhood and parental involvement. These perceptions may be influenced by several factors irrespective of the actual parental involvement. In fact, parental rejection is not a specific set of actions by parents but a belief held by the child. Thus in a way, parental acceptancerejection is symbolic for the most part (Rohner, 2004). Interestingly, research on brain imaging has shown that the pain of perceived rejection is very real. Several fMRI studies have revealed that the anterior cingulate cortex and the right ventral prefrontal cortex are activated when people feel rejected not unlike in the event of actual physical pain (Eisenberger, Lieberman, \& Williams, 2003; Squire \& Stein, 2003).

With the escalation in divorce rates and the preferential custodial parent being the mother, the father-child relationship is considerably strained possibly leading to troubled ruminations about the relationship. Another factor that needs to be considered in paternal/ maternal involvement is the nature of the involvement i.e., instrumental vs. expressive. In contradiction to the Parson-Bales 
theory of role specialization, fathers tend to be involved in both the instrumental and expressive roles, especially in the middle class income group (Finley \& Schwartz, 2006; Strauss, 1967). Hence, the traditional view of role complementarity i.e., the maternal expressive role vs. the father instrumental role may no longer meet the child's expectation of parental involvement and maybe less common than in the 1950's.

Emerging Adulthood:

Emerging adulthood is a relatively new term used to describe individuals ranging in age from 18 to 25 (recently extended through age 30) (Arnett, 2006). Arnett identifies five main features that typify this group of individuals: Identity exploration, instability, self-focus, feeling in-between, and an age of possibilities. The emerging adulthood phase allows individuals to reflect on their family experiences as they develop a sense of self and plan for the future. One of the salient issues during emerging adulthood involves bridging the experiences with one's parent during childhood and adolescence with the consequences of these experiences in adulthood (Aquilino \& Supple, 2001). There is growing evidence that emerging adulthood is a period of stress (Aquilino \& Supple, 2001). Although there has been extensive research conducted to see the effects of parenting styles and behaviors during adolescence, it is as yet unclear as to the extent that parental influences extend into young adulthood. Internalized attachments to parents may play important roles in determining the extent to which an emerging adult is able to address the developmental tasks of this age period and in a way 
troubled ruminations would act as "baggage" (Finley \& Schwartz, 2010; Schwartz \& Finley, 2010).

Fabricius \& Hall (2000) found that respondents wanted to have spent more time with their fathers as they were growing up. They also wanted equal time with each parent as part of the living arrangements post-divorce, which included free and frequent access to the noncustodial parent. Research also shows how a disruptive and inflexible visitation schedule with their fathers lessened the enjoyment or benefit from the visitation making it difficult to enhance relationships with their fathers (Wallerstein \& Lewis, 1998). In their research, Fabricius \& Hall (2000) found that both men and women wanted significantly more time with their fathers than they actually had.

Troubled Ruminations:

The 'troubled ruminations' construct is a new attachment-based construct that was introduced by Finley and Schwartz in 2010 (Finley \& Schwartz, 2010; Schwartz \& Finley, 2010). It alludes to the feeling among young adults that one or both of their parents caused pain in their families, that the non-resident parent was not interested in spending time with them, that their parents may not have loved them, and that they are dissatisfied with their relationships with one or both parents. Thus, 'troubled ruminations' serve as a negative internal working model of parent-child relationships. While it may not imply severe pathology, troubled ruminations could impair an emerging adult's quality of life (Schwartz \& Finley, 2010). Troubled Ruminations were related to low self-esteem and life satisfaction as well as high psychological distress and romantic relationship problems 
(Schwartz \& Finley, 2010). According to symbolic interaction theory, individuals tend to view themselves, as they believe their parents viewed them.

Consequently, children who feel that their parents did not love them are more likely to feel unlovable (Cooley, 1902; Mead, 1934).

Since troubled ruminations as a construct was introduced only in 2010 , there has been no follow up research done on this construct. However, prior to the introduction of the troubled ruminations construct, there have been studies regarding attachment theories, internal working models, parental acceptancerejection and expressive-instrumental parental roles which provide a conceptual framework for the current research on the relationship between desired parental involvement and troubled ruminations.

The troubled ruminations construct draws on attachment theory (Main, 1996) and acceptance-rejection theory (Rohner, 2004). According to acceptancerejection theory, children and adults appear to organize their perceptions of parental acceptance and rejection around four classes of behavior: warmthaffection, hostility-aggression, indifference-neglect and undifferentiated rejection. Of particular interest to the current research, is the evidence that children and adults who experience their relationship with parents as being rejecting tend universally to self-report a specific form of psychological maladjustment that overlaps those found to correlate with troubled ruminations reported by Schwartz \& Finley (2010). Especially in divorced homes, troubled ruminations could have special importance. In an interesting longitudinal study of 54 pairs of former spouses, Ahrons (1981) found that one of the items least often discussed by the 
participants was the children's reactions and adjustments to the divorce as it generated conflicts between the spouses, thus leaving unresolved doubts and apprehensions about the reasons for the divorce in the child's mind.

According to Demo (1992), the consequences of maternal employment, divorce, and single parent family structure have been exaggerated. There is still more research that suggests that adverse effects on children are caused to some extent by divorce or living in a single parent family, but are not nearly as dramatic or permanent as they are believed to be (Demo \& Acock, 1988; Demo, 1992; Emery, 1982). A significant relationship between desired parental involvement during childhood and adolescence and troubled ruminations about parents during young adulthood may be able to provide an insight into the extent to which childhood experiences carry over into adulthood. The rates of divorce and marital separation, unfortunately, only seem to be worsening with time and hence understanding the impact could help us work towards taking the right steps in remedying the gap left in parental involvement.

\section{Child Gender}

Since troubled ruminations about parents as a construct is grounded in attachment theory, the attachment literature acts as a good source to investigate potential gender differences in the current study. Unfortunately prior research on gender differences is largely inconclusive, with research providing evidence in support of both sides of the argument i.e. no gender differences (Feldman, 
Gowen, \& Fisher, 1998) or gender differences in some attachment dimensions (Lopez, 1996).

There is some evidence, however of gender differences in the divorce literature. According to Wenk et al. (1994), the relationships with mothers and fathers are salient determinants of sons' and daughter's wellbeing. However, the basis of this wellbeing may differ. While sons primarily gain their sense of worth from achievement in activities, daughters tend to gain their sense of worth from a sense of social and moral acceptability. Thus, the perception of feeling loved and close to parents is of particular importance to daughters. In their study, Wallerstein \& Kelly (1980) reported that boys had more father contact than girls soon after the divorce; however the sex of the child was no longer significantly associated with the amount of contact 18 months after the divorce. In similar research involving child gender post-divorce, it was seen that fathers' contact with daughters decreased rapidly over time (Hess \& Camara, 1979).

\section{Hypotheses}

The current study investigates 3 hypotheses:

1. Desired parental involvement (DPI) during childhood is positively correlated to troubled ruminations (TR) during young adulthood.

Hypothesis one is a logically derived hypothesis, where participants who demonstrate a higher mean score for desired parental involvement would also demonstrate a higher rating on troubled ruminations. The nature of involvement desired, i.e. instrumental or expressive, will be examined. 
2. The association between desired parental involvement and troubled ruminations about fathers and mothers would be higher for participants from divorced/separated homes than those from intact homes.

Divorced families tend to have a larger degree of inter-parental conflict and stress pre- and post-divorce. Dealing with the pain can take time, with individuals within the same family also perceiving the divorce experience differently. Very often, the pain is accompanied with a sense of guilt, which may impact one's subsequent wellbeing (Guttman, 1993). Further, and as divorce literature confirms, the degree of parental involvement is lesser as compared to intact families. As young adults from intact homes do not experience such early trauma, the frequency of troubled ruminations in such a sample would be less.

\section{The association between desired parental involvement and troubled} ruminations would be greater for fathers than for mothers in young adults from divorced/separated families.

Given the current social/legal policies favoring the mother and the resulting non-resident role assigned to the father after divorce, paternal involvement tends to wane over a period of time. This decrease in paternal involvement could result in a prolonged negative perspective about the father's involvement during childhood extending to adulthood. In a study conducted by Drill (1987), it was found that when a non-custodial parent, usually the father, was seen as 'lost', the young adult was more depressed. Although there are 
conflicting findings, it appears that contact with the non-custodial parent, which more often than not is the father, can be linked to the child's psychological adjustment post-divorce (Arditti, 1993).

\section{METHOD}

Design

Data for the present study are taken from a larger project focusing on maternal and paternal nurturance and involvement (Finley, Mira \& Schwartz, 2008). Data were gathered from two large public universities. To include a diversity of ethnicity, 80 percent of the data were gathered at a public university in southeastern Florida comprising a Hispanic majority and 20 percent of the data were gathered at another public university in northern Florida with a non-Hispanic White student majority.

Participants

The original study consisted of 1,714 young adult university students (75 percent female; mean age 19.90; SD 3.52, 92.1 percent between 18 and 29) from intact as well as divorced families. Participants were asked to rate whomever they felt were the most important mother and father figures in their lives. The vast majority of fathers (91 percent) rated were biological fathers. Six percent were stepfathers, 0.5 percent were adoptive stepfathers and 2 percent were other father figures (e.g. grandfathers, uncles, etc.). In terms of mother figures rated, 98 percent were biological mothers, 1 percent were adoptivemothers and less than 1 percent rated adoptive stepmothers or other mother 
figures. Only those participants with both the biological parents identified as their most important parent figure were used in the present study in order to control for confounds potentially arising from different parent figures. In addition, participants who resided with their fathers at any time after the divorce were not included in order to reflect the more prominent family form consisting of a nonresident father.

Half of all participants were freshmen with the remainder being sophomores (19 percent), juniors (17 percent), seniors (12 percent) or graduate students ( 2 percent). In terms of ethnicity, 57 percent $(n=811)$ of the participants were Hispanic, 24 percent $(n=338)$ were non-Hispanic White, and 13 percent $(n=182)$ were non-Hispanic Black. The remaining 6 percent fell in to 'Asian', 'other' or had failed to mention their ethnicity. This 6 percent was not used while testing for the effect of ethnicity on desired parental involvement and troubled ruminations about parents. The majority (74 percent) of participants were born in the United States, whereas the majority of mothers (70 percent) and fathers (69 percent) were born abroad. The most common countries of origin for immigrant participants and parents (in descending order) were Cuba, Colombia, Nicaragua, Haiti and Jamaica.

Of those participants reporting socioeconomic status (during the participant's adolescence), 14 percent of participants reported annual family incomes below $\$ 30,000 ; 25$ percent between $\$ 30,000$ and $\$ 50,000 ; 36$ percent between $\$ 50,000$ and $\$ 100,000,15$ percent between $\$ 100,000$ and $\$ 150,000$, and 10 percent above 150,000 . Of the total sample set used for the present 
study, 41 percent of fathers and 37 percent of mothers were college graduates, whereas 14 percent of fathers and 9 percent of mothers had not graduated high school.

Of the 1,413 participants included in the present analyses, 73 percent $(n=$ 1,026) were from intact families, and 27 percent $(n=387)$ were from divorced families. Of the 1,413 participants, 25 percent $(n=349)$ were males and 75 percent $(n=1,064)$ were females. The mean participant age at the time of divorce was 8.2 years ( $S D 5.2$, range 0 to 22). Participants from the full dataset, but not included in these analyses, included those reporting the death of one or both parents (2.2 percent; $n=39$ ), those rating a non-biological mother or father figure (9.5 percent; $n=162$ ), those reporting that their parents had never been married (0.5 percent $n=8$ ), participants from divorced families who resided with their fathers at any time following divorce (4 percent; $n=69$ ), and those who did not provide family form data (3.5 percent; $n=60)$.

Measures

\section{Troubled Ruminations about Parents}

The measure developed by Schwartz and Finley (2010) for Troubled Ruminations about Parents was used for the analyses. Three of the four scale items were selected from the Painful feelings About Divorce (PFAD) measure developed by Laumann-Billings and Emery (2000). They focused on those items that were applicable to participants from both intact as well as divorced families and reflected a ruminative or regretful tone regarding past relationships with 
parents. The PFAD items are numbers 1, 2 and 3. The final four Troubled Ruminations items are:

1. "There have been times when I wondered if my father (mother) even loved me."

2. "My father (mother) caused most of the pain in my family."

3. "I wish my father (mother) had spent more time with me when I was younger."

4. "Overall satisfaction with your relationship with your father (mother) The first three items use a 4-point Likert type scale ranging from 1 (strongly disagree) to 4 (strongly agree). The item indexing overall satisfaction with one's mother and father were answered using a 5-point Likert Type scale ranging from 1 (very low) to 5 (very high). The overall satisfaction items were reverse coded such that higher means reflect higher troubled ruminations. A factor analysis showed that all items loaded on one factor and the Cronbach's alpha coefficients for scores on the troubled ruminations about fathers $(\alpha=.82)$ and troubled ruminations about mothers $(\alpha=.78)$ demonstrated adequate internal consistency.

\section{Maternal and Paternal Desired Involvement}

Mother and father involvement, both 'reported' as well as 'desired' involvement, were each assessed in 20 domains of parenting drawn primarily from Hawkins and Palkovitz (1999). From each domain, participants were asked to indicate, on a scale of 1 (much less involved) to 5 (much more involved), how 
involved they would have wanted their mothers and fathers to be (relative to the level of involvement reported). A sample item from this scale reads,

“ developing competence ," where the participant is

instructed to indicate reported involvement on the left side and desired involvement on the right. In the response scale for desired involvement, 1 corresponds to 'much less involved', 2 corresponds to 'a little less involved', 3 corresponds to 'it was just right', 4 to 'a little more involved' and 5 corresponds to 'much more involved.' The Cronbach's alpha estimates for desired instrumental fathering was .91 and for desired expressive fathering was .91. The Cronbach's alpha estimates for desired instrumental mothering was .88 and for desired expressive mothering was .89 (Finley, Mira, \& Schwartz, 2008).

\section{Procedure}

In the original study, participants completed the nurturance and involvement scales, along with psychosocial functioning measures that were not analyzed for the current study. The order of the nurturance and involvement measures (mother first versus father first) was counterbalanced to control for order effects. Most participants came to a research laboratory where they completed the measures individually in sessions of 10 participants each. Some participants completed their measures in class. Participants completed the entire assessment battery within approximately 30 minutes. Data were gathered between September 2004 and January 2006. 


\section{RESULTS}

Hypothesis 1

Desired parental involvement (DPI) during childhood is positively correlated to troubled ruminations (TR) during young adulthood.

Hypothesis I was tested by correlating reports of desired paternal and maternal involvement with troubled ruminations about fathers and mothers respectively. In order to obtain a single score, a mean was calculated for the twenty items on the desired parental involvement scale. Similarly, a mean was calculated for the 4 items on the troubled ruminations scale. The fourth item in the troubled ruminations scale was reverse coded in order to be comparable with the remaining three items in the scale. The first stage of the analysis included a correlation test to determine the relationship between desired parental involvement and troubled ruminations (See Table 1). Overall, there was a significant correlation between desired paternal involvement and troubled ruminations about fathers $(r=.369, p<0.001)$ Similarly, there was a significant correlation between desired maternal involvement and troubled ruminations about mothers $(r=0.201, p<0.001)$. 
Table 1: Correlation between overall desired parental involvement (DPI) and troubled ruminations (TR) about fathers and mothers

\begin{tabular}{|c|c|c|}
\hline \multirow{2}{*}{ DPI_Father } & Pearson Correlation & TR \\
\cline { 2 - 3 } & Sig. (2-tailed) & $.369^{* *}$ \\
\cline { 2 - 3 } & $\mathrm{N}$ & 0.000 \\
\hline \multirow{3}{*}{ DPI_Mother } & Pearson Correlation & 1,413 \\
\cline { 2 - 3 } & Sig. (2-tailed) & $.201^{* *}$ \\
\cline { 2 - 3 } & $\mathrm{N}$ & 0.000 \\
\hline
\end{tabular}

**. Correlation is significant at the 0.01 level (2-tailed).

Hypothesis 2

The association between desired parental involvement and troubled ruminations about fathers and mothers would be higher for participants from divorced/separated homes than those from intact homes.

Figure 1 and Figure 2 demonstrate the higher positive correlation between desired parental involvement and troubled ruminations about fathers and mothers for participants from divorced homes as compared to those from intact homes. However this difference was not statistically significant (See Table 2).

On further analysis of the subscales of desired parental involvement, i.e. instrumental and expressive, however, there was strong evidence for a greater association between desired paternal involvement (instrumental) and troubled ruminations about fathers in female children of divorce as compared to female children from intact families. $\left(\chi^{2}(2)=10.041, p=.002\right)$. However, there was only moderate evidence for a greater association between desired maternal involvement (instrumental) and troubled ruminations about mothers in female 
children of divorce. $\left(\chi^{2}(2)=4.041, p=.044\right)$. No such differences were observed for male children of divorce on the basis of family form and nature of desired parental involvement (See Table 3).

Table 2: Correlation between desired parental involvement (DPI) and troubled ruminations (TR) about fathers and mothers, according to family form

\begin{tabular}{|c|c|c|c|}
\hline \multirow{2}{*}{ Father } & Pearson Correlation & Intact & Divorced \\
\cline { 2 - 4 } & Sig. (2-tailed) & $.294^{* *}$ & $.373^{* *}$ \\
\cline { 2 - 4 } & $\mathrm{N}$ & 0 & 0 \\
\hline \multirow{3}{*}{ Mother } & Pearson Correlation & $.163^{* *}$ & $.258^{* *}$ \\
\cline { 2 - 4 } & Sig. (2-tailed) & 0 & 0 \\
\cline { 2 - 4 } & $\mathrm{N}$ & 1,010 & 389 \\
\hline
\end{tabular}

${ }^{* *}$. Correlation is significant at the 0.01 level (2-tailed). 
Figure1. Scatterplot for desired paternal involvement and troubled ruminations about fathers for intact and divorced homes

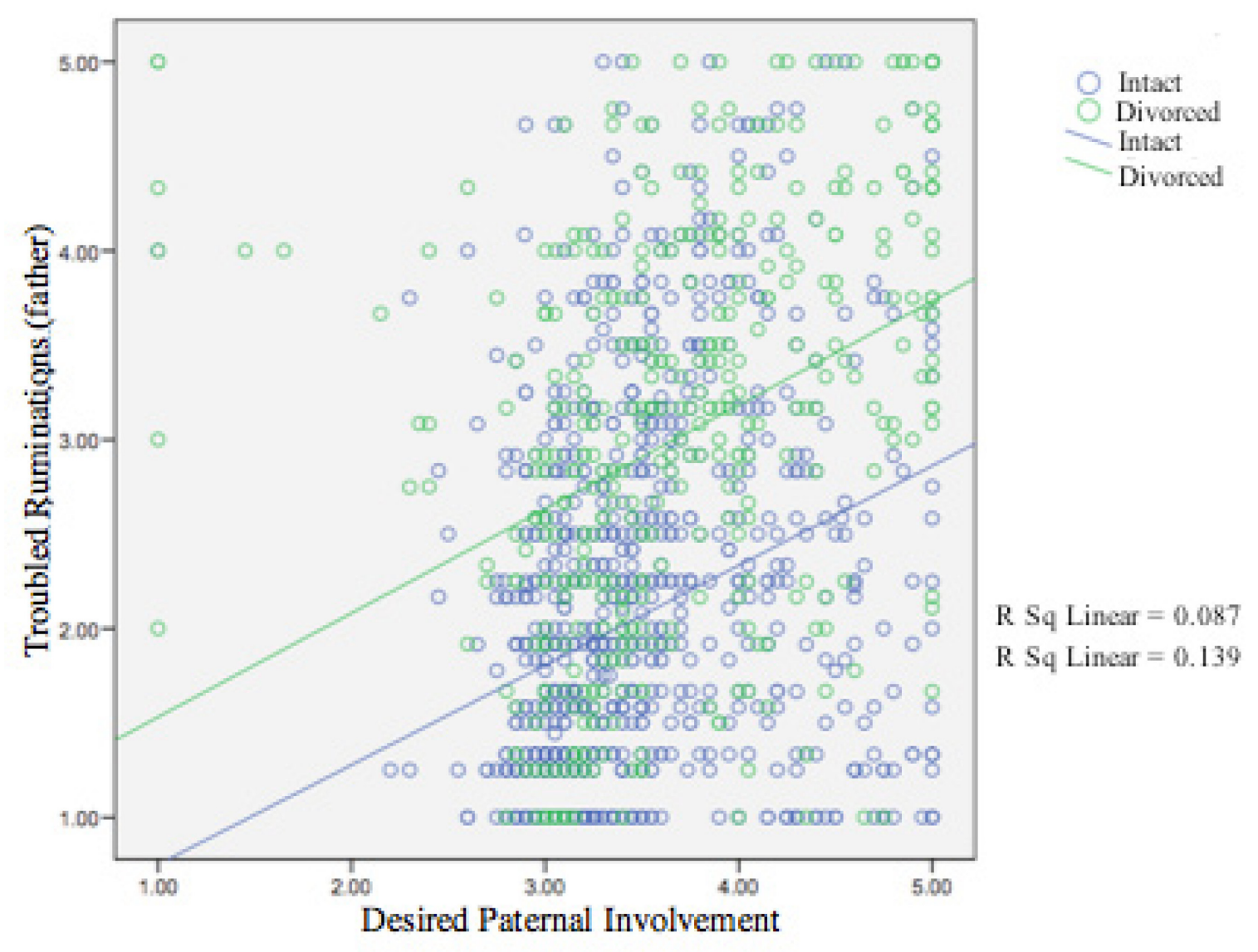


Figure2. Scatterplot for desired maternal involvement and troubled ruminations about mothers for intact and divorced homes

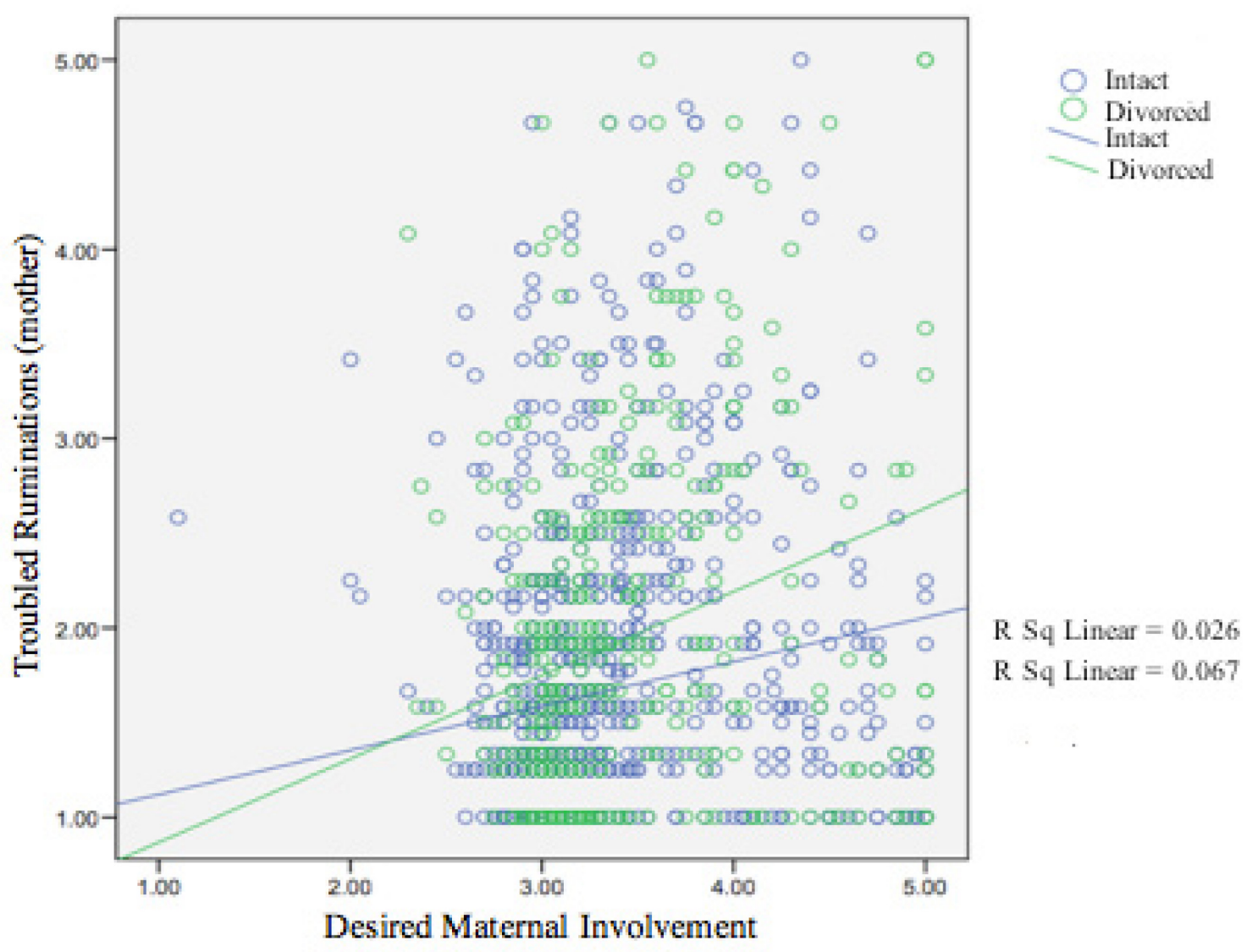


Table 3: Correlation between subscales of desired parental involvement (DPI) and troubled ruminations (TR) about fathers and mothers, according to family form and child gender.

\begin{tabular}{|c|c|c|c|c|c|}
\hline & \multicolumn{2}{|c|}{ Male child } & \multicolumn{2}{|c|}{ Female child } \\
\hline & & \multicolumn{4}{|c|}{ TR (Father) } \\
\hline & & Intact & Divorced & Intact & Divorced \\
\hline \multirow{3}{*}{ DPI_expressive } & $\begin{array}{c}\text { Pearson } \\
\text { Correlation }\end{array}$ & $.375^{* *}$ & $.303^{* *}$ & $.411 * *$ & $.377^{* *}$ \\
\hline & Sig. (2-tailed) & 0.000 & 0.002 & 0.000 & 0.000 \\
\hline & $N$ & 249 & 100 & 763 & 301 \\
\hline \multirow{3}{*}{ DPI_instrumental } & $\begin{array}{c}\text { Pearson } \\
\text { Correlation }\end{array}$ & $.154^{*}$ & $.358 * *$ & $.130 * *$ & $.334 * *$ \\
\hline & Sig. (2-tailed) & 0.015 & 0.000 & 0.000 & 0.000 \\
\hline & $\mathrm{N}$ & 248 & 100 & 763 & 301 \\
\hline & & \multicolumn{4}{|c|}{ TR (Mother) } \\
\hline & & Intact & Divorced & Intact & Divorced \\
\hline \multirow{3}{*}{ DPI_expressive } & $\begin{array}{c}\text { Pearson } \\
\text { Correlation }\end{array}$ & 0.091 & 0.171 & $.271^{* *}$ & $.332 * *$ \\
\hline & Sig. (2-tailed) & 0.152 & 0.094 & 0.000 & 0.000 \\
\hline & $\mathrm{N}$ & 248 & 97 & 762 & 292 \\
\hline \multirow{3}{*}{ DPI_instrumental } & $\begin{array}{l}\text { Pearson } \\
\text { Correlation }\end{array}$ & 0.024 & 0.077 & $.072^{*}$ & $.208^{* *}$ \\
\hline & Sig. (2-tailed) & 0.707 & 0.456 & 0.047 & 0.000 \\
\hline & $N$ & 248 & 97 & 762 & 292 \\
\hline
\end{tabular}

${ }^{* *}$. Correlation is significant at the 0.01 level (2-tailed).

*. Correlation is significant at the 0.05 level (2-tailed).

Hypothesis 3

The association between desired parental involvement and troubled

ruminations would be greater for fathers than for mothers in young adults from divorced/separated families.

Hypothesis 3 was tested by following the procedure outlined by Raghunathan, Rosenthal and Rubin, (1996), for comparing correlated but non- 
overlapping correlations. The analysis indicated a significant difference between the correlations of desired maternal involvement and troubled ruminations for mothers $(r=.248)$ and desired paternal involvement and troubled ruminations for fathers ( $r=.411), p<.001$, in divorced families (See Table 4).

Table 4: Correlation between desired parental involvement (DPI) and troubled ruminations (TR) about fathers and mothers in divorced families

\begin{tabular}{|c|c|c|}
\hline & & Divorced \\
\hline \multirow[t]{3}{*}{ Father } & Pearson Correlation & $.411 * *$ \\
\hline & Sig. (2-tailed) & 0.000 \\
\hline & $\mathrm{N}$ & 387 \\
\hline \multirow[t]{3}{*}{ Mother } & Pearson Correlation & $.248 * *$ \\
\hline & Sig. (2-tailed) & 0.000 \\
\hline & $\mathrm{N}$ & 387 \\
\hline
\end{tabular}

**. Correlation is significant at the 0.01 level (2-tailed).

Note: Only those participants who had provided information for BOTH fathers and mothers were included in this analysis.

Effect of gender:

Finally, the differences in desired parental involvement on the basis of gender of the child were analyzed. The nature of parental involvement: expressive or instrumental may be differentially affected by divorce (Finley \& Schwartz, 2006) (See Table 3). As mentioned in hypothesis 2, there was strong evidence of a greater association between desired paternal involvement (instrumental) and troubled ruminations about fathers in female children of divorce as compared to female children from intact families. $\left(\chi^{2}(2)=10.041, p=\right.$. 002). However, there was only moderate evidence of a greater association between desired maternal involvement (instrumental) and troubled ruminations 
about mothers in female children of divorce as compared to female children from intact families. $\left(\chi^{2}(2)=4.041, p=.044\right)$. There were no other significant differences found based on gender and nature of parental involvement.

\section{DISCUSSION}

My study advances the research on desired parental involvement by exploring the relationship between desired parental involvement during childhood and troubled ruminations about both fathers and mothers in young adulthood. It also investigates the changes in the association between desired parental involvement and troubled ruminations on the basis of family form and child gender.

The present study yields three important insights. First, desired parental involvement (DPI) during childhood is positively correlated to troubled ruminations (TR) during young adulthood. While early-attachment literature provides important insight into the development and impact of attachment figures during childhood, there is still a lot to be learnt about how early-attachment figures impact young adults and the processes that allow an individual to change attachment figures. This association between desired parental involvement during childhood with troubled ruminations during young adulthood provides insight into the role of parents as primary attachment figures and the extent to which childhood attachment figures influence early adult life. 
Second, although the association between desired parental involvement and troubled ruminations about parents was found to be higher for participants from divorced/separated homes as compared to those from intact homes, the difference was not statistically significant. However, on further analysis of the subscales of desired parental involvement there was strong evidence for a greater association between desired paternal involvement (instrumental) and troubled ruminations about fathers in female children of divorce as compared to female children from intact families. Although attachment literature is inconclusive about gender differences in early-attachment figures, the divorce literature provides some evidence for differential perceptions in parental involvement on the basis of child gender (Wenk et al., 1994, Wallerstein \&Kelly, 1980).

Third, the association between desired parental involvement and troubled ruminations was found to be significantly greater for fathers as compared to mothers in young adults from divorced/separated families. This is an important finding in light of the current legal and social policies favoring the mother as the preferential custodial parent and reducing the role of the father to that of child support.

Limitations

The present study draws from a sample of young adult university students. This may result in the exclusion of young adults who are less socially and academically competent and thus may limit generalization. Furthermore, the retrospective reports used for the purpose of the study could be subject to recall 
bias. On the other hand, they may reflect a more 'mature' response to the questions rather than a 'rebellious' one from an adolescent. In addition, a young adult is generally financially less dependent on parents and hence at more liberty to respond truthfully.

The use of a largely ethnic minority and immigrant sample may not be representative of the current ethnic distribution in the United States. However, this may not be a serious drawback of the study as the ethnic minority issue can be seen as a reflection of the growing representation of ethnic minorities and immigrants in the United States.

Another important limitation of the study is the absence of information regarding each participant's custody arrangements and the frequency of father 'visits' following divorce. A non-resident father may still be actively involved in his child's life following divorce.

\section{Conclusion}

Troubled ruminations about parents in young adulthood have been shown to be significantly related to low self-esteem, lack of purpose in life, poor life satisfaction, romantic relationship problems and psychological stress (Schwartz \& Finley, 2010). In divorce, current legal practices lean towards maternal custody. However, this study shows a higher correlation between desired parental involvement and troubled ruminations for fathers as compared to mothers in children of divorce. The present findings thus have important implications for the optimal post-divorce family form, such as equal shared parenting. The findings also could have implications for counseling young adults 
with troubled parental ruminations. Finally, the correlation between a desire for increased parental involvement and troubled parental ruminations highlights the importance of parental involvement during childhood and adolescence. Thus, the findings further could serve as an impetus to parents and to society to reconsider the long-term importance of parental involvement and especially paternal involvement in the lives of the young adult children of divorce. 


\section{REFERENCES}

Ahrons, C. R. (1981). The continuing coparental relationship between divorced spouses. American Journal of Orthopsychiatry, 51(3), 415-428.

Ainsworth, M. D. S., Blehar, M. C., Waters, E., \& Wall, S. (1978). Patterns of attachment: A psychological study of the strange situation. Oxford, England: Lawrence Erlbaum.

Ainsworth, M. S. (1989). Attachments beyond infancy. American Psychologist, 44(4), 709-716. doi:10.1037/0003-066X.44.4.709

Almeida, D. M., \& Galambos, N. L. (1991). Examining father involvement and the quality of father-adolescent relations. Journal of Research on Adolescence, 1(2), 155-172. doi:10.1207/s15327795jra0102_3

Aquilino, W. S., \& Supple, A. J. (2001). Long-term effects of parenting practices during adolescence on well-being: Outcomes in young adulthood. Journal of Family Issues, 22(3), 289-308. doi:10.1177/019251301022003002

Arditti, J. A. (1993) Visitation Frequency, Child support payment, and the Fatherchild relationship post-divorce. Journal of Marriage and Family, 55, 699-712

Arnett, J. J. (2006). Emerging adulthood: Understanding the new way of coming of age. In J. J. Arnett, \& J. L. Tanner (Eds.), (pp. 3-19). Washington, DC, US: American Psychological Association. doi:10.1037/11381-001

Barnett, R. C., \& Baruch, G. K. (1987). Determinants of fathers' participation in family work. Journal of Marriage \& the Family, 49(1), 29-40. doi: $10.2307 / 352667$

Booth, A. (1998). Men in families : When do they get involved? : What difference does it make? Retrieved

Bowlby, J. (1980). Attachment and loss. New York, NY, US: Basic Books.

Cooley, C. H. (1902). Human nature and the social order.

Coverman, S., \& Sheley, J. F. (1986). Change in men's housework and childcare time, 1965-1975. Journal of Marriage \& the Family, 48(2), 413-422. doi: $10.2307 / 352409$

Demo, D. H., \& Acock, A. C. (1988). The impact of divorce on children. Journal of Marriage \& the Family, 50(3), 619-648. doi:10.2307/352634 
Demo, D. H. (1992). Parent-child relations: Assessing recent changes. Journal of Marriage \& the Family, 54(1), 104-117. doi:10.2307/353279

Drill, R. L. (1987) Young adult children of divorced parents: Depression and the perception of loss. Journal of Divorce, 10, 169-187.

Dudley, J. R. (1991). Increasing our understanding of divorced fathers who have infrequent contact with their children. Family Relations: An Interdisciplinary Journal of Applied Family Studies, 40(3), 279-285. doi:10.2307/585012

Eisenberger, N. I., Lieberman, M. D., \& Williams, K. D. (2003). Does rejection hurt? an fMRI study of social exclusion. Science, 302(5643), 290-292. doi:10.1126/science.1089134

Emery, R. E. (1982). Interparental conflict and the children of discord and divorce. Psychological Bulletin, 92(2), 310-330. doi:10.1037/00332909.92.2.310

Fabricius, W. V., \& Hall, J. A. (2000). Young adults' perspectives on divorce: Living arrangements. Family \& Conciliation Courts Review, 38(4), 446-461.

Fabricius, W. V. (2003). Listening to children of divorce: New findings that diverge from wallerstein, lewis, and blakeslee. Family Relations: An Interdisciplinary Journal of Applied Family Studies, 52(4), 385-396. doi:10.1111/j.1741-3729.2003.00385.x

Feldman, S. S., Gowen, L. K., \& Fisher, L. (1998). Family relationships and gender as predictors of romantic intimacy in young adults: A longitudinal study. Journal of Research on Adolescence, 8(2), 263-286. doi:10.1207/s15327795jra0802_5

Finley, G. E., Mira, S. D., \& Schwartz, S. J. (2008). Perceived paternal and maternal involvement: Factor structures, mean differences, and parental roles. Fathering, 6(1), 62-82. doi:10.3149/fth.0601.62

Finley, G. E., \& Schwartz, S. J. (2006). Parsons and bales revisited: Young adult children's characterization of the fathering role. Psychology of Men \& Masculinity, 7(1), 42-55. doi:10.1037/1524-9220.7.1.42

Finley, G. E., \& Schwartz, S. J. (2010). The divided world of the child: Divorce and long-term psychosocial adjustment. Family Court Review, 48(3), 516527. doi:10.1111/j.1744-1617.2010.01326.x 
Furstenberg, F. F., Jr, Nord, C. W., Peterson, J. L., \& Zill, N. (1983). The life course of children of divorce: Marital disruption and parental contact. American Sociological Review, 48(5), 656-668.

Greenberger, E., Goldberg, W. A., Crawford, T. J., \& Granger, J. (1988). Beliefs about the consequences of maternal employment for children. Psychology of Women Quarterly, 12(1), 35-59. doi:10.1111/j.1471-6402.1988.tb00926.x

Guttman, J. (1993). Divorce in a psychosocial perspective. Hillsdale, NJ: Lawrence Erlbaum Associates.

Hartman, L. R., Magalhães, L., \& Mandich, A. (2011). What does parental divorce or marital separation mean for adolescents? A scoping review of north american literature. Journal of Divorce \& Remarriage, 52(7), 490-518. doi:10.1080/10502556.2011.609432

Hawkins, A. J., \& Palkovitz, R. (1999). Beyond ticks and clicks: The need for more diverse and broader conceptualizations and measures of father involvement. The Journal of Men's Studies, 8, 11-32.

Hess, R. D., \& Camara, K. A. (1979). Post-divorce family relationships as mediating factors in the consequences of divorce for children. The Journal of Social Issues, 35(4), 79-96.

Hoffman, L. W. (1974). Effects of maternal employment on the child: A review of the research. Developmental Psychology, 10(2), 204-228. doi:10.1037/h0035981

King, V. (1994). Nonresident father involvement and child well-being: Can dads make a difference? Journal of Family Issues, 15(1), 78-96. doi:10.1177/019251394015001004

Koch, M. A. P., \& Lowery, C. R. (1984). Visitation and the noncustodial father. Journal of Divorce, 8(2), 47-65.

Lamb, M. E., Pleck, J. H., Charnov, E. L., \& Levine, J. A. (1987). In Lancaster J. B., Altmann J., Rossi A. S. and Sherrod L. R. (Eds.), A biosocial perspective on paternal behavior and involvement. Hawthorne, NY, US: Aldine Publishing Co.

Laumann-Billings, L., \& Emery, R. E. (2000). Distress among young adults from divorced families. Journal of Family Psychology, 14, 671-687. 
Lopez, F. G. (1996). Attachment-related predictors of constructive thinking among college students. Journal of Counseling \& Development, 75(1), 58-63. doi:10.1002/j.1556-6676.1996.tb02315.x

Main, M. (1996). Introduction to the special section on attachment and psychopathology: 2. overview of the field of attachment. Journal of Consulting and Clinical Psychology, 64(2), 237-243. doi:10.1037/0022006X.64.2.237

Mead, G. H. (1934). Mind, self, and society from the standpoint of a social behaviorist. University of Chicago Press: Chicago.

Miller, A. J., Sassler, S., \& Kusi-Appouh, D. (2011). The specter of divorce: Views from working- and middle-class cohabitors. Family Relations, 60(5), 602-616. doi:10.1111/j.1741-3729.2011.00671.x

Parcel, T. L., \& Menaghan, E. G. (1990). Maternal working conditions and children's verbal facility: Studying the intergenerational transmission of inequality from mothers to young children. Social Psychology Quarterly, 53(2), 132-147. doi:10.2307/2786675

Pleck, J. H. (1979). Men's family work: Three perspec-tives and some new data. The Family Coordinator, 28, 481-488.

Robinson, J. P., \& Milkie, M. A. (1998). Back to the basics: Trends in and role determinants of women's attitudes toward housework. Journal of Marriage \& the Family, 60(1), 205-218. doi:10.2307/353452

Rohner, R. P. (2004). The parental "acceptance-rejection syndrome": Universal correlates of perceived rejection. American Psychologist, 59(8), 830-840. doi:10.1037/0003-066X.59.8.830

Schwartz, S. J., \& Finley, G. E. (2005). Fathering in intact and divorced families: Ethnic differences in retrospective reports. Journal of Marriage and Family, 67(1), 207-215. doi:10.1111/j.0022-2445.2005.00015.x

Schwartz, S. J., \& Finley, G. E. (2010). Troubled ruminations about parents: Conceptualization and validation with emerging adults. Journal of Counseling \& Development, 88(1), 80-91.

Spillman, J. A., Deschamps, H. S., \& Crews, J. A. (2004). Perspectives on nonresidential paternal involvement and grief: A literature review. The Family Journal, 12(3), 263-270. doi:10.1177/1066480704264347 
Squire, S., \& Stein, A. (2003). Functional MRI and parental responsiveness: A new avenue into parental psychopathology and early parent-child interactions? British Journal of Psychiatry, 183(6), 481-483.

doi:10.1192/bjp.183.6.481

Stephens, L. S. (1996). Will johnny see daddy this week? an empirical test of three theoretical perspectives of postdivorce contact. Journal of Family Issues, 17(4), 466-494. doi:10.1177/019251396017004003

Strauss, M. (1967). The influence of sex of child and social class on instrumental and expressive family roles in a laboratory setting. Sociology and social research, 52, 7-21

Tepp, A. V. A. (1983). Divorced fathers: Predictors of continued paternal involvement. The American Journal of Psychiatry, 140(11), 1465-1469.

Wallerstein, J. S., \& Lewis, J. (1998). The long-term impact of divorce on children: A first report from a 25-year study. Family \& Conciliation Courts Review, 36(3), 368-383.

Wallerstein, J. S., \& Kelly, J. B. (1980). Surviving the breakup : How children and parents cope with divorce / judith S. wallerstein and joan berlin kelly. Basic Books.

Watson, J. S. (1972). Smiling, cooing, and "the game.". Merrill-Palmer Quarterly: Journal of Developmental Psychology, 18(4), 323-339.

Wenk, D., Hardesty, C. L., Morgan, C. S., \& Blair, S. L. (1994). The influence of parental involvement on the well-being of sons and daughters. Journal of Marriage \& the Family, 56(1), 228-234. doi:10.2307/352718 